\title{
TRABALHO, PRECARIZAÇÃO E RESISTÊNCIAS: novos e velhos desafios? ${ }^{1}$
}

\author{
Graça Druck*
}

\begin{abstract}
O artigo discute por que a precarização social do trabalho é um novo e velho fenômeno, é diferente e igual, é passado e presente, um fenômeno de caráter macro e microssocial. Apresenta alguns fetiches presentes nas análises sobre o trabalho no contexto de mundialização do capital, marcado pela hegemonia do capital financeiro, pela reestruturação da produção e do trabalho e por um "novo espírito do capitalismo". São cinco seções: introdução; discussão sobre aspectos metodológicos a partir de reflexões de projetos de pesquisa em andamento; considerações teóricas sobre a caracterização do capitalismo flexível e a centralidade da precarização social do trabalho; contextualização do trabalho na América Latina e no Brasil à luz dos estudos da OIT, indicadores de precarização e de resistências; e debate os velhos e novos desafios trazidos pelas transformações sob a égide da precarização social do trabalho e de um "espírito do capitalismo" reformulado, que, ao mesmo tempo em que reafirma o velho espírito, constitui um novo espírito.

PALAVRAS-CHAVE: trabalho, precarização, resistências, indicadores sociais.
\end{abstract}

O artigo tem por objetivo apresentar três conjuntos de questões de naturezas diversas, que estão presentes em pesquisas cujas temáticas estão inseridas no debate sobre as transformações do trabalho nas últimas quatro décadas. Mais especificamente, busca-se tratar da precarização social do trabalho e das formas atuais de resistência numa perspectiva que contemple desafios de caráter metodológico, de conteúdo teórico e de análise de realidades empíricas.

Grande parte das pesquisas produzidas depara-se com essas questões. Portanto, não há novidade alguma ao se destacar esses desafios. Entretanto, pretende-se abordá-los de forma articulada, de tal modo que as escolhas metodológicas não apenas sejam coerentes com os elementos * Doutora em Ciências Sociais, com pós-doutorado na Universidade de Paris XIII. Professora associada I do Departamento de Sociologia e da Pós-Graduação em Ciências Sociais da Universidade Federal da Bahia - PPGCS/ FFCH/UFBA. Pesquisadora do Centro de Recursos Humanos/FFCH/UFBA e do CNPq.

Faculdade de Filosofia e Ciências Humanas. Estrada de São Lázaro, 197. Federação, Cep: 40.210-730. Salvador, Bahia - Brasil. druckg@gmail.com

${ }^{1}$ Este artigo contou com a colaboração de Selma Silva, Bolsista de Pós-doutorado do PNPD/Capes, a quem agradeço a elaboração e atualização dos dados da PNAD. Agradeço também a sua leitura, os comentários e sugestões que foram, em sua maioria, incorporados ao texto. conceituais e de investigação de realidades concretas, mas expliquem a formulação de categorias mediadoras para a compreensão das transformações, tendências e continuidades ou reconfigurações trazidas sob a égide da precarização social do trabalho.

É com essa perspectiva que se pretende defender que o mundo do trabalho contemporâneo, na transição do século XX para o século XXI, vivencia uma rede de transformações cuja complexidade só pode ser desvendada a partir de uma perspectiva histórico-dialética. As contradições histórico-sociais do trabalho não permitem conclusões apressadas ou definitivas sobre rupturas e novas formas de trabalho ou de relações sociais, pois, ao lado de novas condições e situações sociais de trabalho, velhas formas e modalidades se reproduzem e se reconfiguram, num claro processo de metamorfose social.

Portanto, pretende-se explicitar por que a precarização social do trabalho é um novo e um velho fenômeno, por que é diferente e igual, por que é passado e presente e por que é um fenômeno de caráter macro e microssocial. Para tal 
empreitada, discutem-se alguns dos mitos e fetiches $^{2}$ estatísticos que têm influenciado as análises sobre o trabalho e os trabalhadores no atual contexto de mundialização do capital, marcado pela hegemonia do capital financeiro, de uma nova reestruturação da produção e do trabalho e de um "novo espírito do capitalismo", ${ }^{3}$ como formulado por Luc Boltanski e Ève Chiapello (2009).

Para atingir esses objetivos, dividiu-se o texto em quatro seções, além desta introdução. A primeira enuncia alguns aspectos e preocupações metodológicas, a partir de reflexões sobre projetos de pesquisa em andamento. A segunda apresenta algumas considerações de caráter teórico, a fim de avançar na precisão do momento histórico, da caracterização do capitalismo flexível e da centralidade da precarização social do trabalho. A terceira contextualiza, à luz dos estudos da OIT, o quadro do trabalho e do emprego na América Latina e no Brasil, apresentando alguns indicadores de precarização social e de resistência dos trabalhadores. E a quarta seção pretende enunciar algumas reflexões na tentativa de explicitar quais são os velhos e os novos desafios trazidos pelas transformações sob a égide da precarização social do trabalho e de um "espírito do capitalismo” reformulado, redefinido, que reafirma o velho espírito ao tempo que renova e constitui um novo espírito.

A noção de fetiche aplicada neste artigo, conforme explicado na seção "algumas reflexões metodológicas", referese aos processos de análise que absolutizam e autonomizam as informações quantitativas ou qualitativas, naturalizando o dado e os considerando como a própria realidade (cf. Bresson, 1995).

${ }^{3}$ Trata-se do título do livro desses autores, que analisa as transformações do capitalismo nos tempos atuais e as mudanças ideológicas, à luz dos fundadores da Sociologia, especialmente Max Weber, tendo por objetivo principal revelar as relações que se estabelecem entre o capitalismo e seus críticos. Consideram como “espírito”, “... a ideologia que justifica o engajamento no capitalismo" (p. 39), buscam compreender como esse novo espírito conseguiu neutralizar a crítica social e apresentam uma proposta que desnaturalize o social, historicizando-o numa perspectiva de contraposição à perplexidade ideológica e de reforço à resistência ao fatalismo intelectual que tomou conta da esquerda e de grande parte da intelectualidade francesa. Título original do livro: Le Nouvel Esprit du Capitalisme. Paris: Gallimard, 1999. Traduzido e publicado no Brasil como O Novo Espírito do Capitalismo, São Paulo:Martins Fontes, 2009. p.700

\section{ALGUMAS REFLEXÕES METODOLÓGICAS}

Este artigo recupera alguns referenciais metodológicos que foram se explicitando no desenrolar de uma pesquisa que venho desenvolvendo sobre a construção de indicadores sociais da precarização social ${ }^{4}$ no Brasil. Nela, toma-se por referência a definição de "indicador social" de Januzzi (2003):

\begin{abstract}
Um indicador social é uma medida em geral quantitativa dotada de significado social substantivo, usado para substituir, quantificar ou operacionalizar um conceito social abstrato, de interesse teórico (para pesquisa acadêmica) ou programático (para formulação de políticas). É um recurso metodológico, empiricamente referido, que informa algo sobre um aspecto da realidade social ou sobre mudanças que estão se processando na mesma.

Para a pesquisa acadêmica, o Indicador Social é, pois, o elo de ligação entre os modelos explicativos da Teoria Social e a evidência empírica dos fenômenos sociais observados (p.15).
\end{abstract}

Observa-se que os indicadores sociais são classificados como: quantitativos (ou objetivos), construídos a partir de estatísticas e fontes secundárias ou de informações quantitativas de estudos de casos e (ou) surveys; e qualitativos (ou subjetivos), constituídos por pesquisas de cunho qualitativo, que utilizam estudos de casos de vários tipos (locais, setoriais, regionais, longitudinais etc.) através de pesquisa direta e fontes primárias e que também formam uma base de dados significativa nos estudos das ciências sociais no Brasil.

Após dois anos de pesquisa, algumas observações merecem ser acrescentadas a essas considerações. Em primeiro lugar, um esclarecimento no que se refere aos indicadores quantitativos, ou com base em estatísticas. É fundamental não se deixar levar pelo fetiche dos números. Isso porque, quando se compreende o quantitativo como só objetividade, a tendência é autonomizar o nú-

${ }^{4}$ Trata-se do projeto de pesquisa A Precarização Social do Trabalho no Brasil: uma proposta de construção de indicadores, apresentado em 2007 e iniciado em 2008. Projeto apresentado ao CNPq para obtenção de Bolsa produtividade, aprovado, realizado com apoio também da Capes/ PNPD, desde 2008, e do PIBIC/UFBa/CNPq. 
mero da sua própria origem, da sua construção e representatividade.É essa autonomização que leva à absolutização do quantitativismo, reconhecendo-se as estatísticas como única fonte legítima de conhecimento da realidade e de sua veracidade, impondo-as a outras formas de conhecimento, de dados e informações de pesquisas que não são "objetivas" e, portanto, "científicas".

De acordo com Besson (1995), as estatísticas são resultados de observação de fatos e não uma simples operação de medida. Os "fatos" são construídos, e a observação é um processo de definição do objeto. Assim, "As estatísticas não refletem a realidade, refletem o olhar da sociedade sobre si mesma" (p.19). Toda informação estatística é resultado de um trabalho de conceituação, organização e observação e de exploração (p.19). Trata-se, portanto, de relativizar essa objetividade das informações quantitativas, pois:

Por detrás das informações estatísticas se encontra um modelo conceitual, por meio do qual a realidade é filtrada. As categorias são definidas e os casos, resolvidos. Todo quadro de cifras tem assim uma dupla natureza: qualitativa e quantitativa. Sua estrutura, os títulos das linhas e das colunas traduzem a modelização preliminar do fenômeno (p.47).

No que se refere às informações de caráter qualitativo, também a fetichização se manifesta quando, ao desqualificar as estatísticas pelo seu caráter globalizante e massificante, que reduz os homens a números, a uma contagem, reafirma-se a qualidade do subjetivo, do individual, do singular, como único caminho para o conhecimento "real" da realidade social. Trata-se do mesmo tipo de equívoco, já que, mais uma vez, absolutiza-se o método de produção da informação como se ele fosse o preciso e exato conhecimento do real. Não se leva em conta que as informações obtidas, interpretadas e analisadas, são todas dotadas de representações conceituais e ideológicas e, portanto, estão sendo construídas pelos homens que pesquisam e pelos pesquisados, como sujeitos e atores do processo de sua produção e dos resultados que sin- tetizam. Mais uma vez, vale retomar Besson (1995):

O fetichismo estatístico nasce da confusão do índice com a realidade. Ele infecta constantemente não só os 'quantitativistas', mas também numerosos 'qualitativistas'. Os primeiros acreditam; os segundos, não; os dois desconhecem as condições da produção da estatística, o caráter normal e inevitável das convenções, das contingências, dos fluxos que a acompanham. Os primeiros não querem vê-las; os segundos, quando as percebem, fazem de tudo para rejeitar as estatísticas; os dois dividem a mesma concepção absolutista do conhecimento (p.49).

É nessa perspectiva que se propôs a construção de um conjunto de Indicadores de Precarização do Trabalho e de Resistências que procurasse combinar informações de naturezas diversas e complementares: (a) as estatísticas cujas bases de dados são elaboradas por instituições oficiais do estado e, por isso, são credenciadas e sancionadas socialmente, como o IBGE, além de outras bases específicas da área de Trabalho e Emprego, que estão sob a responsabilidade do Ministério do trabalho e do Emprego (MTe), do Ministério Público do Trabalho (MPT), da Justiça do Trabalho (JT) e do Instituto Nacional de Seguro Social (INSS), inclusive em parceria com instituições já amplamente reconhecidas, como é o caso do DIEESE ${ }^{5}$ - e (b) as bases de dados que reúnem resultados de pesquisas qualitativas, individuais e coletivas, cujos estudos são locais, setoriais, de casos específicos, e conseguem traduzir situações variadas de trabalho, de emprego e de desemprego, que as estatísticas, por serem classificações padronizadas e codificadas, não podem revelar. É o caso de publicações individuais de resultados de projetos, de teses e dissertações, que apresentam a diversidade regional, setorial e de diferentes segmentos de trabalhadores, bem como das suas diferentes inserções e condições de trabalho.

Nessa medida, a intenção é de fugir aos fetiches e às armadilhas que as informações quantitativas e qualitativas podem levar, mesmo que as

${ }^{5}$ DIEESE - Departamento Intersindical de Estatística e Estudos Socioeconômicos. 
dificuldades para tal sejam grandes. Isso porque se observa, tanto no campo da grande imprensa como nos estudos acadêmicos, uma tendência ao uso de "cifras fetiches", como exemplifica Besson (1995), ou de casos paradigmáticos, que são tratados de forma retórica, acentuando-se e dramatizando-se a sua representatividade, nos quais se substitui o todo pela parte e se confunde o real com a síntese que as informações - qualitativas e quantitativas - representam desse real. ${ }^{6}$

Assim, as estatísticas não são medidas ou fotografias quantitativas, mas resultados de observações e, portanto, não são nem verdadeiras nem falsas. Quando se pergunta se os números são precisos, é necessário reconhecer que “... toda observação estatística tem um grau de inexatidão. Isso porque “... as estatísticas são imagens de síntese, que representam não as situações individuais, mas a média dessas situações." (Besson, 1995, p.32, grifo meu).

Por sua vez, os estudos qualitativos não podem substituir as observações estatísticas. Eles também são resultados de observações, cuja codificação e classificação são de outra natureza, pois não precisam ser validados oficialmente, mas, necessariamente, tem de ter aceitação e, portanto, um tipo de validação e reconhecimento entre seus pares, isto é, entre os pesquisadores da área temática da qual fazem parte. Dessa forma, também são portadores de uma síntese e, por isso, se constituem numa linguagem comum que dá inteligibilidade às situações de trabalho, emprego e desemprego, por exemplo.

${ }^{6} \mathrm{O}$ autor se refere ao uso de números fetiches, a exemplo de número de mortos nas estradas, número de desempregados, etc., que vêm acompanhados da afirmação “...háx anos não acontecia, esta é a $1^{\mathrm{a}}$ vez depois de x anos", cujo objetivo é dramatizar, diferenciar, escandalizar, a fim de deixar a marca da informação nos que a ouvem e, em geral, desconhecem a sua origem ou como são construídas, escolhidas e o que representam. indicadores sociais. No caso das estatísticas de trabalho, emprego e renda, há que se pensar na estabilidade ou instabilidade das categorias conceituais, ainda mais quando se consideram as rápidas transformações no mundo do trabalho. Essa é uma preocupação permanente dos profissionais que constroem as estatísticas. No caso do seu uso, a combinação de dados e a construção de indicadores é uma alternativa para acompanhar as transformações. Isso porque há uma relativa liberdade na formulação de indicadores, pois se podem combinar, de forma diferente, diversos indicadores, assim como construir novos, mesmo tendo por base as "velhas" estatísticas. De toda forma, a produção de estatísticas assim como de indicadores é acionada pelas transformações da realidade socioeconômica. Novas categorias conceituais e novas séries históricas são implementadas porque os fatos novos exigem observação, codificação, classificação e explicação.

Por fim, considera-se que toda produção de estatísticas, de informações e dados, assim como o seu uso por estudiosos, é fruto de escolhas. E essas escolhas revelam uma postura científica e ideológica que influencia decisivamente as modalidades qualitativas e quantitativas de pesquisas. Por isso, a subjetividade e a objetividade são indissociáveis tanto numa modalidade como na outra. Nem os números, nem os fatos, nem o "campo empírico" da pesquisa falam por si mesmos. Por isso, a proposta de um projeto de pesquisa para a construção de Indicadores de Precarização Social do Trabalho já revela, em sua denominação, uma escolha a partir de um posicionamento crítico frente à atual realidade do trabalho e que, por sua vez, difere da denominação dos Indicadores de Trabalho Decente, formulada pela OIT. Entretanto, o objetivo não é contrapor uma denominação a outra. Ao contrário, busca-se demonstrar que a apropriação das estatísticas e pesquisas sobre o trabalho, nas últimas décadas no mundo, na América Latina e no Brasil, indica o mesmo processo: um "déficit de trabalho decente" ou um quadro de precarização social do trabalho.

E, para deixar explícita essa escolha, resgata-se aqui o que está afirmado no projeto de pes- 
quisa (Druck, 2007, p.19-20), quando introduz o conceito temático a partir do qual se pretende construir os indicadores:

No caso do estudo proposto, o conceito temático do qual se parte para a construção de indicadores é a Precarização Social do Trabalho, compreendida como um processo em que se instala - econômica, social e politicamente - uma institucionalização da flexibilização e da precarização moderna do trabalho, que renova e reconfigura a precarização histórica e estrutural do trabalho no Brasil, agora justificada pela necessidade de adaptação aos novos tempos globais $[\ldots]$

O conteúdo dessa (nova) precarização está dado pela condição de instabilidade, de insegurança, de adaptabilidade e de fragmentação dos coletivos de trabalhadores e da destituição do conteúdo social do trabalho. Essa condição se torna central e hegemônica, contrapondo-se a outras formas de trabalho e de direitos sociais duramente conquistados em nosso país, que ainda permanecem e resistem.

O trabalho precário em suas diversas dimensões (nas formas de inserção e de contrato, na informalidade, na terceirização, na desregulação e flexibilização da legislação trabalhista, no desemprego, no adoecimento, nos acidentes de trabalho, na perda salarial, na fragilidade dos sindicatos) é um processo que dá unidade à classeque-vive-do-trabalho e que dá unidade também aos distintos lugares em que essa precarização se manifesta. Há um fio condutor, há uma articulação e uma indissociabilidade entre: as formas precárias de trabalho e de emprego, expressas na (des)estruturação do mercado de trabalho e no papel do Estado e sua (des) proteção social, nas práticas de gestão e organização do trabalho e nos sindicatos, todos contaminados por uma altíssima vulnerabilidade social e política.

\section{O ATUAL MOMENTO DA ACUMULAÇÃO FLEXÍVEL: a precarização como estratégia de dominação}

Primeiramente, pretende-se apresentar uma reflexão acerca do atual momento histórico, em que o trabalho assume uma determinada configuração que se tornou hegemônica em termos mundiais há, pelo menos, quatro décadas. É a era identificada como de uma mundialização inédita do capital, apoiada num projeto político e econômico de cunho neoliberal e que se concretizou essencialmente através de uma reestruturação in- tensa e longa da produção e do trabalho.

Parte-se, portanto, da caracterização de uma nova fase do capitalismo contemporâneo, também denominado de flexível (Sennett, 1999) ou de acumulação flexível (Harvey, 1995). E, nessa denominação, já está subjacente a compreensão de que o sistema capitalista, em seu desenvolvimento histórico, sofreu transformações significativas - especialmente no campo do trabalho e das lutas dos trabalhadores - que redefiniram a sua configuração, mesmo que mantivessem sua essência como um sistema cujas relações sociais se assentam sobre o trabalho assalariado, ou seja, pela apropriação do trabalho pelo capital, através da compra e venda da força de trabalho no mercado, independentemente das formas de contrato existentes ou predominantes.

Assim, é o processo de acumulação ilimitada de capital que comanda a sociedade, numa busca insaciável pelo lucro, pela produção do excedente, cada vez mais estimulada pela concorrência intercapitalista no plano mundial. Um processo que dissocia o capital e as formas materiais de riqueza (valores de uso), conferindo-lhes um caráter abstrato, cuja valorização através do trabalho excedente garante perpetuar-se a acumulação.

Entretanto, na história do capitalismo, estabeleceram-se diferentes padrões de acumulação, frutos de um conjunto de fatores econômicos, sociais e políticos, destacadamente as lutas de resistência dos trabalhadores, que colocaram limites à acumulação, redefinindo e implementando direitos sociais e trabalhistas, assim como a aceitação e legitimação, pela sociedade e pelo Estado, da proteção social como um direito a ser garantido.

São conjunturas históricas que atuam sobre as condições estruturais do sistema e o modificam, interferindo sobre as suas formas e configurações. São, portanto, momentos que sintetizam determinadas relações de forças das ações das classes sociais, cujas experiências também variam historicamente. O que se quer dizer, em síntese, é que o capitalismo do século XIX não é o mesmo do século XX, e muito menos o do século XXI.

Entretanto, as diferentes conjunturas histó- 
ricas e as transições de uma era a outra evidenciam processos de transformação em que velhas e novas formas de trabalho e emprego coexistem, são combinadas e, ao mesmo tempo, se redefinem, indicando um típico movimento de metamorfose, que, no atual momento, se dá sob a égide de uma dinâmica que passa a predominar sobre outras: é a dinâmica da precarização social do trabalho.

A acumulação flexível, que tão bem caracteriza o capitalismo contemporâneo, tem sua origem na busca por superar uma conjuntura de crise de outro padrão de desenvolvimento capitalista, marcado pelo fordismo e por um regime de regulação cuja experiência mais completa se deu nos países que conseguiram implementar um estado de bem-estar, experiência que nem mesmo na Europa se generalizou.

Não se trata de retomar aqui o debate sobre a crise do fordismo. Entretanto, vale comparar algumas características daquela crise e o atual contexto após 40 anos de alternativas ao velho padrão fordista de desenvolvimento. Como foi muito bem observado por Boltanski e Chiapello (2009), contrariamente à crise dos anos 1970, o quadro hoje é de “... coexistência entre a degradação da situação econômica e social de um número crescente de pessoas e um capitalismo em plena expansão e profundamente transformado" (p.19).

Nas análises da crise do fordismo, havia um consenso que apontava uma situação de saturação da produção em massa, com queda no ritmo da produtividade nos principais países do mundo e queda da lucratividade. No capitalismo flexível, embora o crescimento econômico tenha se desacelerado, a lucratividade aumentou, e os ganhos do capital nunca foram tão altos e tão rápidos. No ambiente socioeconômico dos países que fizeram a experiência dos Estados de Bem-estar ou de políticas públicas de pleno emprego, em resposta à crise de 1929, o fordismo representou uma sociedade em que o progresso econômico e social atingiu amplos segmentos e onde era possível planejar o futuro das novas gerações, pois as condições de trabalho e emprego permitiam algum tipo de vínculo de longo prazo.

Conforme Boltanski e Chiapello (2009), no contexto dos anos 1960, além de um padrão de vida que permitia planejar o progresso social, havia um ambiente político de grande mobilização e crítica aos padrões capitalistas, o que desembocou no maio de 68. As lutas sociais contra as diferentes formas de desigualdade no trabalho, na escola, na família, de gênero, raça e geração tiveram uma forte expressão e levaram a protestos no mundo inteiro.

Na era da acumulação flexível, as transformações trazidas pela ruptura com o padrão fordista geraram outro modo de trabalho e de vida pautado na flexibilização e na precarização do trabalho, como exigências do processo de financeirização da economia, que viabilizaram a mundialização do capital num grau nunca antes alcançado. Houve uma evolução da esfera financeira, que passou a determinar todos os demais empreendimentos do capital, subordinando a esfera produtiva e contaminando todas as práticas produtivas e os modos de gestão do trabalho, apoiada centralmente numa nova configuração do Estado, que passa a desempenhar um papel cada vez mais de "gestor dos negócios da burguesia”, já que ele age agora em defesa da desregulamentação dos mercados, especialmente o financeiro e o de trabalho.

Conforme já foi afirmado em outros escritos (Druck, 2007, 2010), essa hegemonia do setor financeiro ultrapassa o terreno estritamente econômico do mercado e impregna todos os âmbitos da vida social, dando conteúdo a um novo modo de trabalho e de vida. Trata-se de uma rapidez inédita do tempo social, sustentado na volatilidade, efemeridade e descartabilidade sem limites de tudo o que se produz e, principalmente, dos que produzem - os homens e mulheres que vivem do trabalho. É isso que dá novo conteúdo à flexibilização e à precarização do trabalho, que se metamorfoseiam, assumindo novas dimensões e configurações. O curto prazo - como elemento central dos investimentos financeiros impõe processos ágeis de produção e de trabalho, e, para tal, é indispensável contar com trabalhadores que se submetam a quaisquer condições para atender ao novo ritmo e às rápidas mudanças.

Assim, a mesma lógica que incentiva a permanente inovação no campo da tecnologia e dos 
novos produtos financeiros, atinge a força de trabalho de forma impiedosa, transformando rapidamente os homens que trabalham em obsoletos e descartáveis, que devem ser "superados" e substituídos por outros "novos" e "modernos", isto é, flexíveis. É o tempo de novos (des)empregados, de homens empregáveis no curto prazo, através das (novas) e precárias formas de contrato.

Nesta era, de um "novo espírito do capitalismo" (Boltanski; Chiapello, 2009), o capital leva até as últimas consequências o fim único de fazer mais dinheiro do dinheiro, não mais tendo como meio principal a produção em massa de mercadorias, mas sim a especulação financeira, pautada na volatilidade, na efemeridade, no curtíssimo prazo, sem estabelecer laços ou vínculos com lugar nenhum, sem compromissos de nenhum tipo a não ser com o jogo do mercado (financeiro em primeiro lugar), pautado numa desmedida concorrência internacional que não aceita qualquer tipo de regulação.

Assim, não é mais o padrão da sociedade do pleno emprego, mas o de uma sociedade de desempregados e de formas precárias de trabalho, de emprego e de vida que passa a predominar também onde se tinha atingido um alto grau de desenvolvimento econômico e social, a exemplo dos países que tiveram as experiências dos Estados de Bem-Estar Social.

Trata-se, segundo Castel (1998), da precarização do trabalho como elemento central da nova dinâmica do desenvolvimento do capitalismo, criando uma nova condição de vulnerabilidade social: um processo social que modifica as condições do assalariamento (estável) anteriormente hegemônico no período da chamada sociedade salarial ou fordista. A perda do emprego ou a perda da condição de uma inserção estável no emprego cria uma condição de insegurança e de um modo de vida e de trabalho precários, nos planos objetivo e subjetivo, fazendo desenvolver a ruptura dos laços e dos vínculos, tornando-os vulneráveis e sob uma condição social fragilizada, ou de “desfiliação" social (Druck, 2011a).

Afirmar que a precarização social do trabalho está no centro da dinâmica do capitalismo flexí- vel significa também entendê-la como uma estratégia de dominação. Isto é, força e consentimento são os recursos que o capital se utiliza para viabilizar esse grau de acumulação sem limites materiais e morais. A força se materializa principalmente na imposição de condições de trabalho e de emprego precárias frente à permanente ameaça de desemprego estrutural criado pelo capitalismo. Afinal, ter qualquer emprego é melhor do que não ter nenhum. Aplica-se aqui, de forma generalizada, o que Marx e Engels elaboraram acerca da função política principal do "exército industrial de reserva", 7 qual seja: a de criar uma profunda concorrência e divisão entre os próprios trabalhadores e, com isso, garantir uma quase absoluta submissão e subordinação do trabalho ao capital, como única via de sobrevivência para os trabalhadores. O consenso se produz a partir do momento em que os próprios trabalhadores, influenciados por seus dirigentes políticos e sindicais, passam a acreditar que as transformações no trabalho são inexoráveis e, como tal, passam a ser justificadas como resultados de uma nova época ou de um "novo espírito do capitalismo".

Esse "novo espírito" insiste em desqualificar os valores construídos na era anterior, fazendo desmoronar a crença no progresso, nas possibilidades de emprego e de direitos sociais de longo prazo e num Estado protetor. Em nome da "via única” e do "pensamento único", impõe um conjunto de mudanças que passam a ser justificadas no plano material e intelectual como uma força da natureza e, portanto, sem possibilidades de uma intervenção humana. Para Boltanski e Chiapello (2009), nesse processo, identifica-se uma "perplexidade ideológica" que atinge todos os segmentos críticos da sociedade (intelectuais, sindicatos, partidos) que, em nome de um "fatalismo dominante", não dão vazão à sua indignação e acabam por se resignar diante dessa "força avassaladora" do capitalismo flexível. ${ }^{8}$

${ }^{7}$ Ver, particularmente, em K. Marx, O Capital, Capítulo XXIII Livro I.

${ }^{8}$ Os autores definem que seu principal objetivo é compreender o enfraquecimento da "crítica" numa perspectiva histórica, que resultou num fatalismo dominante, isto é, numa "desnaturalização do social”, a fim de reforçar a resistência ao fatalismo, sem, no entanto, cair num saudosismo em relação ao passado. 
Nas palavras de Bourdieu (1998), essa transição apoia-se na flexibilidade como "estratégia de precarização”, inspirada por razões econômicas e políticas, produto de uma "vontade política" e não de uma "fatalidade econômica", que seria dada, supostamente, pela mundialização. Nela, considerase a precarização como um

... regime político [...] inscrita num modo de dominação de tipo novo, fundado na instituição de uma situação generalizada e permanente de insegurança, visando a obrigar os trabalhadores à submissão, à aceitação da exploração (Bourdieu, 1998, p.124-125).

Esse regime é constituído por vontades (ativas ou passivas) de poderes políticos e, portanto, não pode ser explicada por "leis inflexíveis" de um regime econômico, mas sim por escolhas orientadas para preservar a dominação cada vez mais completa do trabalho e dos trabalhadores (Druck, 2007).

Mais uma vez, o que as formulações acima estão a tratar é de um fenômeno novo e velho: o fetiche do mercado que se desdobra em diferentes expressões, a exemplo do fetiche da flexibilização, isto é, de sua autonomização frente aos homens em suas relações sociais e de trabalho, como uma inversão entre sujeito e objeto. E a flexibilização passa a determinar o comportamento dos sujeitos como uma força exterior e natural, sem que eles os sujeitos - sejam capazes de reagir e reassumir o controle sobre os processos sociais.

Nessa conjuntura histórica - da acumulação flexível, de um regime político sustentado na estratégia da precarização, de um capitalismo flexível ou de um novo espírito do capitalismo - é que se busca compreender, no plano de realidades concretas, onde e como a precarização social do trabalho pode ser demonstrada. Para tal, recorre-se a um conjunto de indicadores quantitativos, com base em estatísticas, e qualitativos, a partir de estudos locais, setoriais ou de casos, que serão apresentados na próxima seção.

\section{O QUADRO MAIS GERAL DO TRABALHOE DO EMPREGO NA AMÉRICA LATINA E NO BRASIL NOS ANOS 2000: alguns indicadores}

A Organização Internacional do Trabalho (OIT) criou, em 1999, a Agenda do Trabalho Decente, cuja definição expressa as lacunas e deficiências ou o grau de precarização do trabalho, observados a partir de um diagnóstico sobre a década de 1990, especialmente na América Latina, além de indicar que as transformações do trabalho também fizeram regredir conquistas significativas, redefinindo o patamar dos direitos sociais e trabalhistas em todo o mundo, inclusive nos países mais desenvolvidos.

Segundo a OIT, nos anos 1990, o quadro social e do trabalho, na América Latina e Caribe, revelou graves problemas em decorrência das reformas e políticas aplicadas pelos governos: uma baixa produtividade do trabalho e um aumento do desemprego e da informalidade, com destaque para os países que flexibilizaram suas respectivas legislações, liberalizando as formas de contratos e demissões, diminuindo ou sustando mecanismos de proteção social (aposentadorias, pensões, saúde, acidentes e doenças ocupacionais). Tais ações eram justificadas por uma necessidade de romper com a rigidez desses sistemas de proteção e de relações de emprego, a fim de possibilitar o aumento do emprego formal, com a redução dos custos do trabalho para o empresariado. Essa mesma justificativa se encontrou em nosso país, através da discussão sobre o "Custo Brasil”. Entretanto, os resultados dessas reformas não confirmaram as justificativas, como diagnostica a OIT (2006):

... depois de uma década, a experiência de vários países mostra que, apesar dessas reformas, em lugar do aumento do emprego formal, o que se produziu foi um incremento do desemprego e da informalidade, acentuando-se ainda a precarização dos empregos, associada à insegurança das remunerações, à menor proteção social, à maior rotatividade da força de trabalho etc. Argumentou-se que os maus resultados se deviam ao fato de as reformas não terem sido completadas, ficando na metade do caminho. No entanto, não dispomos de qualquer evidência de 
que uma dose maior de reformas desse tipo traria melhorias a essa situação. Pelo contrário, a experiência recente faz pensar que mais reformas talvez a piorasse ainda mais (p.3).

No documento Emprego, Desenvolvimento Humano e Trabalho Decente: a experiência brasileira recente (OIT, CEPAL, PNUD, 2008), destacase que as características mais gerais do mercado de trabalho, na América Latina e no Brasil, nos anos 2000, mantêm a tendência e os principais problemas que caracterizam a precarização social do trabalho na região, mas apresentam queda na taxa de desemprego, que cai de 11,4\% em 1999 para 8\% em 2007. Entretanto, o documento reconhece que: houve criação insuficiente de postos de trabalho, com um crescimento da produtividade limitado a alguns setores produtivos; parte do crescimento das ocupações foi no trabalho informal; o trabalho nas atividades terciárias (comércio e serviços) ganhou peso; os empregos criados são ainda de baixa qualidade (informais, temporários e sem contratos); aumentou a população ocupada sem direito à seguridade social; os rendimentos do trabalho se deterioraram num significativo número de países (OIT, CEPAL, PNUD, 2008, p.11).

Os recentes documentos da OIT apresentam uma sistematização das informações sobre o quadro mundial e latino-americano do trabalho nas últimas duas décadas, cujas conclusões demonstram não ter ocorrido uma ruptura das tendências e dos indicadores de precarização social do trabalho no período, em que pesem alguns movimentos conjunturais, a exemplo da retomada do crescimento econômico a partir de 2000, que atingiu a maior parte dos países em todo o mundo, com ritmos diferenciados em cada país ou região.

Essas sistematizações e análises da OIT permitem afirmar que a década de 1990 - marcada pela mundialização das políticas neoliberais, pela hegemonia do capital financeiro e pela flexibilização e precarização do trabalho como estratégias centrais - teve a sua continuidade nos anos 2000, sem sofrer inflexão ou ruptura no quadro mais geral do trabalho no mundo. Mesmo considerando alguns resultados, como a diminuição das taxas de de- semprego e a redução de níveis de pobreza para certos países na América Latina, inclusive o Brasil, eles não chegaram a se firmar como tendências consolidadas, pois a crise mundial que se abriu em 2008, em meses, colocou por terra alguns avanços localizados, evidenciando a permanência de uma profunda vulnerabilidade social (Druck; Oliveira; Silva, 2010).

Observa-se, portanto, que as análises da OIT expressam as influências de diferentes conjunturas, e, se não houver clareza sobre a natureza desses movimentos e mudanças, podem-se confundir transformações de caráter conjuntural com aquelas de caráter estrutural.Éo que se pode depreender dos relatórios que analisaram a repercussão da crise mundial aberta em 2008, quando a OIT alertava sobre a gravidade da situação no campo do trabalho e do emprego, com previsões que foram manchetes em vários meios de comunicação, a exemplo da previsão de se atingir o quantitativo de 230 milhões de desempregados no mundo em 2009, com um acréscimo de 40 milhões em relação a 2008.

No World of Work Report 2009 - The Global Jobs crisis and Beyond (2009a), a OIT reconhece que havia sinais de recuperação da economia mundial e que a queda do emprego fora inferior às previsões, devido à intervenção do Estado e dos governos. Entretanto, entre outubro de 2008, quando se iniciou a crise, e o final de 2009, em 51 países com dados disponíveis, foram perdidos 20 milhões de postos de trabalho e 5 milhões de trabalhadores se encontravam numa situação extremamente vulnerável, ameaçados de perder o emprego, já que estavam com jornada de trabalho reduzida, desemprego parcial ou trabalho involuntário em tempo parcial. Além disso, estimava que 45 milhões de trabalhadores poderiam ficar fora do mercado de trabalho, especialmente no caso dos pouco qualificados, imigrantes, mais velhos e os jovens. Também fazia novas previsões para os países emergentes e em desenvolvimento: haveria uma recuperação dos níveis de emprego já em 2010, mas eles não atingiriam os mesmos níveis no período anterior a crise antes de 2011. No 
caso dos países mais ricos, a previsão era de que o emprego não recuperaria o mesmo patamar anterior à crise, antes de 2013.

Para além dos diagnósticos e balanços dos estragos da crise mundial, a $98^{\mathrm{a}}$ Conferência Internacional do Trabalho da OIT, realizada em junho de 2009, adotou o Um Pacto Mundial para o Emprego da OIT, que se constitui num amplo programa de propostas de ações, o qual pede

... a governos e organizações de trabalhadores e empregadores que trabalhem unidos para enfrentar a crise mundial de emprego com políticas que estejam alinhadas com o Programa de Trabalho Decente da OIT (OIT, 2009b, p. 2).

Nesse documento ("Para superar a crise: um pacto mundial para o emprego”), são elencados 28 pontos que estão divididos em quatro diretrizes principais: criação de empregos, aumento da proteção social, respeito aos direitos e às normas internacionais do trabalho e o diálogo social. Todas elas sintetizam a definição de Trabalho Decente da OIT:

O Trabalho Decente é um trabalho produtivo e adequadamente remunerado, exercido em condições de liberdade, equidade, e segurança, sem quaisquer formas de discriminação, e capaz de garantir uma vida digna a todas as pessoas que vivem de seu trabalho [...] Os quatro eixos centrais da Agenda do Trabalho Decente são a criação de emprego de qualidade para homens e mulheres, a extensão da proteção social, a promoção e fortalecimento do diálogo social e o respeito aos princípios e direitos fundamentais no trabalho, expressos na Declaração dos Direitos, adotada em 1998 (MTE, 2006, p.5 grifo do texto original).

Embora a iniciativa da OIT seja muito positiva e represente uma tentativa de reafirmar a Agenda do Trabalho Decente em plena crise mundial, transformando-a numa plataforma de lutas, as propostas contidas no documento partem de uma concepção da conjuntura de crise que omite as condições e as responsabilidades pelo seu desencadeamento. É como se a crise fosse obra das forças incontroláveis da natureza ou do mercado, como um campo que se autonomiza dos sujeitos ou das classes sociais e é exterior a eles. E, dessa forma, a OIT desconsidera as suas próprias análises apresentadas em relató- rios que afirmam sobre as más consequências da financeirização da economia, da desregulamentação dos mercados e da flexibilização do trabalho, adotadas pelos governos dos principais países do mundo em todos os continentes, mesmo que de forma diferenciada. De acordo com o texto Sumário Executivo da OIT (2008, p.2):

A globalização financeira intensificou a instabilidade econômica. Nos anos 90, as crises do sistema bancário foram dez vezes mais frequentes que as do final dos turbulentos anos 70 . O custo deste aumento de instabilidade, em geral, foi pago muito mais pelos grupos de baixa renda. Experiências anteriores sugerem que a perda de empregos ocasionada pelas crises do sistema financeiro foram muito graves, com efeitos mais permanentes nos grupos mais vulneráveis. Também se pode prever que o desemprego aumente como resultado da queda dos investimentos e isto pode intensificar ainda mais as desigualdades de rendimentos. E mais: existem evidências de que a globalização financeira reforçou a tendência descendente na distribuição dos salários registrada na maioria dos países. Por outro lado, a globalização financeira teve um efeito disciplinador sobre as políticas macroeconômicas, tanto nos países desenvolvidos como nos países emergentes.

Assim, compreende-se que a crise mundial atual é produto exatamente desse processo, da ação dos grandes investidores, apoiados nas políticas adotadas pela grande maioria dos seus respectivos governos, que tiveram como central a desregulamentação dos mercados, isto é, a liberalização sem limites para a mobilidade do capital, cujos custos recaíram sobre os trabalhadores, conforme alertado pela OIT, em relatórios sobre o trabalho e o emprego no mundo, nas duas últimas décadas, cujos indicadores expressam um déficit de trabalho decente, ou, dito de outra forma, sinalizam a precarização social do trabalho ainda como predominante.

\section{O caso brasileiro, nesse contexto}

Franco e Druck (2009) elaboraram uma tipologia da precarização, aqui retomada para agrupar alguns indicadores selecionados para a realidade brasileira. 
- O primeiro tipo da precarização do trabalho: vulnerabilidade das formas de inserção e desigualdades sociais

As formas de mercantilização da força de trabalho produziram um mercado de trabalho heterogêneo, segmentado, marcado por uma vulnerabilidade estrutural e com formas de inserção (contratos) precários, sem proteção social, cujas formas de ocupação e o desemprego ainda revelam, em 2009, um alto grau de precarização social.

De acordo com dados da Pesquisa Nacional de Amostra por Domicílios - PNAD 2009, havia 101,1 milhões de pessoas economicamente ativas no Brasil, com 8,4 milhões de desempregados e mais 8,2 milhões de pessoas com ocupações sem remuneração. ${ }^{9} \mathrm{Ou}$ seja, são 16,6 milhões de pessoas $(16,4 \%)$ economicamente ativas que estavam fora do mercado de trabalho.

Quando se analisa a distribuição das pessoas ocupadas com remuneração monetária, elas eram em 2009, no Brasil, 84,5 milhões, dos quais 43,5 milhões sem carteira assinada ${ }^{10} \mathrm{e}$, portanto, sem os direitos trabalhistas garantidos pelo emprego formal, representando $51 \%$ dos ocupados com remuneração. Desse conjunto de trabalhadores sem carteira assinada, 80\% não contribuem para a previdência social. Isso significa que estão sem nenhuma proteção social e trabalhista.

Ao se agruparem os 16,6 milhões de desempregados e sem remuneração com os 43,5 milhões sem carteira assinada, teremos 60,1 milhões de pessoas em condições precárias no que se refere aos direitos básicos do trabalho assalariado, segundo a regulamentação das leis brasileiras, o que representa $59 \%$ das pessoas economicamente ativas.

Tais números revelam um cenário de alta precarização, em termos das formas de ocupação e de direitos sociais e trabalhistas, que o mercado de trabalho brasileiro ainda apresenta, indicando,

\footnotetext{
${ }^{9}$ São dados da PNAD 2009, e, nas ocupações sem remuneração, estão agrupados os trabalhadores para consumo próprio, os trabalhadores na construção para uso próprio e o trabalho não-remunerado.

${ }^{10}$ Estão agrupados, na categoria dos "sem carteira”, os empregados sem carteira, o trabalhador doméstico sem carteira, o trabalhador por conta própria e o empregador.
}

dessa forma, que o país expressa uma realidade de trabalho ainda distante dos indicadores de trabalho decente definidos pela OIT.

Esses dados confirmam tendências apresentadas pela OIT, CEPAL e PNUD (2008), ${ }^{11}$ quando examinam o desempenho do mercado de trabalho brasileiro no período 1990 a 2006. Embora se evidencie uma situação de recuperação nos anos 2000 em relação à década de 1990, por conta da retomada do crescimento econômico, principalmente a partir de 2004, ainda se mantém um quadro em que é constatado:

a) Elevadas taxas de desemprego e de informalidade, que resultam em baixo grau de proteção social e inserção inadequada dos trabalhadores; b) expressiva parcela da mão de obra sujeita a baixos níveis de rendimento e produtividade; c) alta rotatividade no emprego; d) alto grau de desigualdade entre diferentes grupos, refletindo um nível significativo de discriminação, sobretudo em relação às mulheres e à população negra. (OIT, CEPAL, PNUD, 2008, p.17 )

Ao se examinar a evolução desse quadro no Brasil, tomando como um ponto de referência o início dos anos 2000, observa-se que, segundo dados da PNAD, em 2001 havia uma população economicamente ativa de 83,2 milhões, 16,4 milhões de pessoas desempregadas e sem remuneração e 38,2 milhões sem carteira assinada, ou seja, 54,4 milhões sem proteção social e trabalhista, representando $66 \%$ das pessoas economicamente ativas. Embora percentualmente a situação fosse pior em 2001, em termos absolutos o número de pessoas sem remuneração e sem carteira assinada era menor.

Nesse período (2001-2009), o crescimento do número de pessoas ocupadas com remuneração foi de $26 \%$ para uma população economicamente ativa que cresceu $22 \%$. Entretanto, o trabalho sem carteira aumentou $43 \%$, enquanto que o trabalho protegido (militares, funcionários públicos e com carteira assinada) cresceu na proporção de $44 \%$, o que se refletiu num aumento dos que contribuem para a previdência social em $44 \%$.

${ }^{11}$ Documento Emprego, Desenvolvimento Humano e Trabalho Decente: a experiência brasileira recente, disponível na HP da OIT, publicado em setembro de 2008. 
Em termos de rendimento mensal, houve um crescimento de $44 \%$ no número de pessoas que recebem menos do que 1 salário mínimo, no período 2001-2009, sendo que esse número cresceu mais entre os empregados sem carteira (43\%), trabalhadores domésticos sem carteira (54\%) e trabalhadores por conta própria (47\%).

Em 2001, eram 12,6 milhões de trabalhadores que recebiam menos do que 1 salário mínimo, que passaram a ser 18,2 milhões em 2009. Em 2001, representavam $19 \%$ dos ocupados com remuneração e, em 2009, passaram a ser 22\%.

O salário mínimo foi objeto de valorização e de recuperação desde meados dos anos 1990, mas com correções mais altas nos anos 2000 , sofrendo uma valorização de $171 \%$ entre 2003 e 2009, ${ }^{12}$ o que teve impactos positivos no conjunto da economia, em especial para os trabalhadores que sobrevivem desse salário. Em 2009, eram 9,7 milhões que ganhavam 1 salário mínimo, ou 7,8\% do total dos ocupados; já em 2001, eram 5,9 milhões ou $7,8 \%$ dos ocupados. Entretanto, é importante registrar que o valor nominal do Salário Mínimo Necessário, calculado pelo DIEESE, deveria ser de $\mathrm{R} \$ 2.227,53$ em dezembro de 2009, quando era de $\mathrm{R} \$ 510,00$, ou seja, 4,4 vezes menor do que o estimado como necessário.

Os principais indicadores do mercado de trabalho para os anos 2000 demonstram uma tendência à recuperação do emprego, com a redução das taxas de desemprego e o aumento do número de empregados com carteira. Essa tendência foi interrompida com a crise mundial de 2008. Assim, quando se analisam as taxas de desemprego urbano no Brasil, após a crise mundial, no período de outubro de 2008 e março de 2009 (IBGE/ PNAD), em apenas 6 meses, os desocupados cresceram 19\%, passando de 1.743 .000 para 2.082.000. Esse é o mesmo percentual de recuperação do desemprego em 5 anos, no período 20032007, quando saiu de um total 2.608.000 desocupados em 2003 para 2.100.000 em 2007. Ou seja, o que o país recuperou em 5 anos, perdeu em 6

${ }^{12}$ Variação do salário mínimo real com base ou aos preços de setembro de 2010 meses, o que evidencia a vulnerabilidade dos empregos no Brasil, indicando as dificuldades de superação dos altos níveis de desemprego, decorrentes da forma de inserção do país na globalização, embora, a partir de agosto de 2009, um novo movimento de recuperação do emprego tivesse sido iniciado, inclusive com o aumento dos "empregados com carteira assinada".

Entretanto, em 2009, permanece um alto nível de desigualdade e de discriminação no mercado de trabalho, especialmente em relação às mulheres, aos negros e aos jovens, que continuam os segmentos mais precários de todos os trabalhadores. A taxa de desemprego das mulheres era de $11,1 \%$ contra $8,3 \%$ da dos homens; o desemprego dos jovens negros era de $18,8 \%$ e dos jovens brancos de 16,5\%. Além dessa desigualdade étnica e de gênero, há também uma brutal diferença geracional, pois a situação de desemprego dos jovens é a mais grave de todas. Em 2009, quando a taxa total de desemprego era de $8,3 \%$, os jovens desempregados entre 15 e 24 anos correspondiam a 18\%. Entre as mulheres jovens, a situação é ainda pior: $22,4 \%$ de desempregadas. E havia 15,9\%, ou 2,1 milhões de jovens entre 15 e 24 anos que não estudavam nem trabalhavam.

\section{Segundo tipo de precarização: intensificação do trabalho e terceirização}

Um segundo tipo de precarização social é encontrado nos padrões de gestão e organização do trabalho - o que tem levado a condições extremamente precárias, através da intensificação do trabalho (imposição de metas inalcançáveis, extensão da jornada de trabalho, polivalência, etc.) sustentada na gestão pelo medo, na discriminação criada pela terceirização, que tem se propagado de forma epidêmica, e nas formas de abuso de poder, através do assédio moral, que tem sido amplamente denunciado e objeto de processos na Justiça do Trabalho e no Ministério Público do Trabalho.

No que diz respeito à terceirização, no início dos anos 1990, numa conjuntura econômica 
de instabilidade e de crise, poder-se-ia afirmar que as empresas justificavam a adoção da terceirização como "ferramenta" ou "estratégia" para sobreviver diante da reestruturação e redefinição das bases de competitividade no plano internacional e nacional (Borges; Druck, 1993; DIEESE, 2007). Entretanto, nos anos 2000, numa conjuntura econômica internacional favorável e de retomada do crescimento para todos os setores, especialmente aqueles estudados nos anos 1990 (automotivo, petroquímica e bancário), não se altera o movimento da terceirização, que continua a crescer em todas as atividades, atingindo agora também o setor público de forma intensa.

Essa "epidemia" da terceirização, como uma modalidade de gestão e organização do trabalho, explica-se pelo ambiente comandado pela lógica da acumulação financeira que, no âmbito do processo de trabalho, das condições de trabalho e do mercado de trabalho, exige total flexibilidade em todos os níveis, instituindo um novo tipo de precarização que passa a dirigir a relação entre capital e trabalho em todas as suas dimensões. E, num quadro em que a economia está toda contaminada pela lógica financeira, sustentada no curtíssimo prazo, mesmo as empresas do setor industrial buscam garantir os rendimentos, exigindo e transferindo aos trabalhadores a pressão pela maximização do tempo, pelas altas taxas de produtividade, pela redução dos custos com o trabalho e pela "volatilidade" nas formas de inserção e de contratos. E a terceirização corresponde, como nenhuma outra modalidade de gestão, a essas exigências (Druck, 2011b).

Os diversos setores pesquisados nos anos 2000, bancários, call centers, petroquímico, petroleiro, além das empresas estatais ou privatizadas de energia elétrica, comunicações e dos serviços públicos de saúde, para além das estatísticas que indicam o crescimento da terceirização, revelam as múltiplas formas de precarização dos trabalhadores terceirizados nessas atividades: nos tipos de contrato, na remuneração, nas condições de trabalho e de saúde e na representação sindical.

\section{- Terceiro tipo de precarização social: insegurança e saúde no trabalho}

O terceiro tipo de precarização social referese às condições de (in) segurança e saúde no trabalho - resultado dos padrões de gestão, que desrespeitam o necessário treinamento, as informações sobre riscos, as medidas preventivas coletivas, etc., na busca de maior produtividade a qualquer custo, inclusive de vidas humanas. Um importante indicador dessa precarização é a evolução do número de acidentes de trabalho no país, mesmo que reconhecidamente sejam estatísticas sub-registradas.$^{13}$ Em 2001, foram registrados 340,3 mil acidentes no país e, em 2009, eles atingiram o número de 723,5 , ou seja, um aumento de $126 \%$ em 9 anos. É interessante observar que, a partir de 2007, o INSS passou a contabilizar os acidentes sem registro no Cadastro de Acidentes do Trabalho (CAT), que representaram para cada um dos últimos 3 anos (2007, 2008 e 2009) $27 \%$ do número total de acidentes. Além desse quadro, os estudos microssociais em empresas e organizações, no campo da Saúde Mental Relacionada ao Trabalho, definem uma "psicopatologia da precarização", produto da violência no ambiente de trabalho, gerada pela imposição da busca de excelência como ideologia da perfeição humana, que pressiona os trabalhadores ignorando seus limites e dificuldades, junto a uma radical defesa e implementação da flexibilidade como "norma" do presente. Isso exige uma adaptação contínua a mudanças e novas exigências de polivalência, de um indivíduo "volátil”, sem laços, sem vínculos e sem caráter, isto é, flexível. Essa condição, agravada por outros imperativos típicos dos chamados padrões modernos de organização empresarial (competitividade exacerbada, rapidez ou velocidade ilimitada), tem gerado um cenário de adoecimento mental com expressões diversas, inclusive os suicídios (Seligmann-Silva, 2001; Franco; Druck; Seligmann-Silva, 2010).

${ }^{13}$ Conforme é alertado pelos estudiosos da saúde do trabalhador, as estatísticas sobre doenças ocupacionais e acidentes de trabalho, sob a responsabilidade do INSS são subestimadas, pois dependem das CATs (Cadastro de Acidentes de Trabalho) emitidas pelas empresas. 
- Quarto tipo de precarização social: perda das identidades individual e coletiva

O quarto tipo de precarização social tem suas raízes na condição de desempregado e na ameaça permanente da perda do emprego, que tem se constituído numa eficiente estratégia de dominação no âmbito do trabalho. O isolamento e a perda de enraizamento, de vínculos, de inserção, de uma perspectiva de identidade coletiva, resultantes da descartabilidade, da desvalorização e da exclusão, são condições que afetam decisivamente a solidariedade de classe, solapando-a pela brutal concorrência que se desencadeia entre os próprios trabalhadores (Druck; Oliveira; Silva, 2010). Essa condição de "desfiliação" ou de "inúteis para o mundo", a que se refere Castel (1998), explica esse segundo tipo de precarização do trabalho: a perda das identidades individual e coletiva, fruto da desvalorização simbólica e real, que condena cada trabalhador a ser o único responsável por sua empregabilidade, deixando-o subjugado à "ditadura do sucesso" em condições extremamente adversas criadas pelo capitalismo flexível (Appay, 2005).

\section{- Quinto tipo de precarização do trabalho:} fragilização da organização dos trabalhadores

O quinto tipo de precarização pode ser identificado nas dificuldades da organização sindical e das formas de luta e representação dos trabalhadores, decorrentes da violenta concorrência entre eles próprios, da sua heterogeneidade e divisão, implicando uma pulverização dos sindicatos, criada, principalmente, pela terceirização. Dados sobre número de greves, sindicatos, sindicalização, acordos, etc. são importantes, mas não explicam tudo. Indicam tendências, mudanças e redefinições que também precisam ser explicadas. $\mathrm{O}$ menor número de greves nos anos 2000 em relação às duas décadas anteriores, o crescimento do número de centrais sindicais - são hoje 11 centrais, 8 delas formadas nos anos $2000^{14}-$, a permanência

${ }^{14}$ Conforme Sistema Integrado de Relações de Trabalho (SIRT) Ministério do Trabalho e do Emprego. ou mesmo queda das taxas de sindicalização, como ocorreu em 2009 em relação a 2008 (16,5 milhões de sindicalizados contra 17,5 milhões, cf. dados IBGE/PNAD, 2009), o tipo de estratégia de ação da maioria das direções sindicais, tudo isso só pode ser compreendido no contexto da "perplexidade ideológica”, conforme já foi referido anteriormente e que será mais explicitado a seguir.

Há indicadores de resistência? Sim, uma resistência de tipo dispersa, fragmentada ou adaptada. A literatura sobre os sindicatos e o movimento dos trabalhadores dos últimos anos tem problematizado sobre a crise dos sindicatos na era da globalização e da reestruturação sob a direção do neoliberalismo em âmbito mundial. Uma das principais justificativas apontadas por Hayek ${ }^{15}$ na defesa da doutrina neoliberal foi a responsabilização dos sindicatos pela crise dos anos 1970, devido a seu excessivo e nefasto poder, influenciando o movimento dos trabalhadores em suas lutas por aumentos salariais e por políticas de bem-estar, que culminaram na deterioração das bases de acumulação do capital e da insustentabilidade de um estado de altos gastos sociais (Anderson, 1995).

Essa justificativa foi, aos poucos, conquistando adesões de governos, lideranças políticas e dirigentes sindicais, naqueles países em que a experiência social-democrata foi mais marcante. É como se houvesse uma mea culpa por parte dos sindicatos, que passaram a reconhecer os limites ou mesmo o fim daquela "era dos 30 anos gloriosos" e que, perplexos diante da ofensiva do capital - nos planos material e ideológico -, não conseguem reagir e oferecer alternativas ao novo padrão de desenvolvimento capitalista que se globaliza.

No caso do Brasil, que não viveu tal experiência, pois não se construiu aqui um pacto socialdemocrata nem um Estado de Bem-estar social, a tragédia neoliberal talvez tenha sido mais forte ainda, pois, antes mesmo de buscar realizar essa experiência, a maioria das direções sindicais, especi-

${ }^{15}$ Friedrich Hayek, autor de O Caminho da Servidão [1944], considerado o texto que deu origem aos princípios teóricos e políticos do neoliberalismo, que tinha como foco o ataque ao Estado de Bem-estar social na Europa, especialmente, o da Inglaterra. 
almente a partir dos anos 1990, passaram a considerá-la inviável diante da "inexorável globalização", ou da referida "modernidade empresarial”, cuja reestruturação produtiva passou a ser assimilada como um processo "natural" e sem volta. Tratava-se, portanto, de ações que limitassem ou minorassem os seus efeitos, num explícito comportamento de adaptação aos "novos tempos globais".

A violência da ofensiva liberal no contexto da globalização foi de natureza material e simbólica. A reestruturação produtiva e do trabalho - via demissões, enxugamentos, terceirização, polivalência -, inspirada no modelo japonês, levou, no plano objetivo, a condições de fragilização dos trabalhadores e de sua capacidade de luta, que foram reforçadas, no plano subjetivo, pela defesa de uma política e uma atuação sindical dentro dos limites dessa nova ordem (neoliberal) do capital, neutralizando a vontade política coletiva no sentido de não apenas resistir, mas de buscar rupturas com essa nova ordem. Talvez, nessa perspectiva, torne-se mais claro compreender as especulações em torno do "fim da história", ou seja, de uma vitória final do capitalismo diante das possibilidades históricas - que agora estariam esgotadas - de sua superação, a exemplo das transformações capitalistas nos países que tinham realizado experiências socialistas.

Para exemplificar esse tipo de adaptação política aos novos tempos liberais e de uma inevitável flexibilização do trabalho, escolheu-se o caso do debate acerca da regulamentação da terceirização no Brasil, a partir dos dois projetos de lei que tramitam no Congresso Nacional. O primeiro deles é de autoria do deputado Sandro Mabel, apresentado em 1998 e reformulado em 2004, que tem por objetivo adaptar a legislação ao processo de "revolução" na organização do trabalho, em que a terceirização é a "técnica de administração" que mais cresce no país. Trata-se, na realidade, de legalizar todas as formas de terceirização que vêm se desenvolvendo, inclusive com a liberação para pessoas físicas como contratantes de serviços de terceiros, o que dificultaria ainda mais qualquer tipo de fiscalização. O outro é o Projeto de Lei $N^{\circ}$
1621 de 2007, de autoria do então deputado Vicentinho (ex-presidente da CUT), que contou com a contribuição da Central Única dos Trabalhadores (CUT) para a sua elaboração. Seus termos, embora o diferenciem em aspectos importantes do Projeto do deputado Mabel - a exemplo da proibição de terceirização de atividades fins, a exigência de a empresa informar e justificar aos sindicatos a implementação da terceirização, o controle da contratante sobre as obrigações trabalhistas da contratada, a exigência de que não haverá distinção de salário, jornada, benefícios, ritmo de trabalho e condições de saúde e de segurança, dentre outros - tem causado muita polêmica no próprio meio sindical e na CUT.

Para a Confederação Nacional dos Químicos (CNQ), que defende a "primeirização"16 dos postos de trabalho e uma campanha nacional de sindicalização, incluindo os trabalhadores da empresa terceirizada, e para o Sindicato dos Químicos e Petroleiros da Bahia, é muito discutível a proposta de regulamentação da CUT, pois

A gente não vai ser a favor de um projeto de lei que regulamente aquilo que a gente quer acabar, embora a gente diga que é difícil acabar. As pessoas dizem que ficar como está não pode. Sim, e aí faz um projeto de lei e o projeto de lei piora em alguns setores em que a terceirização se deu com mais intensidade... (Santana, 2007).

Ainda segundo o depoimento desse dirigente sindical, exatamente nos setores em que a terceirização mais cresceu - industrial e bancário -, houve uma redução muito grande do efetivo de trabalhadores que perderam direitos e se precarizaram (Druck, 2011b).

Esse debate exemplifica certo estado de resignação da maior parte dos dirigentes sindicais brasileiros diante da ofensiva neoliberal, o que leva a justificar uma atuação nos limites e no interior do próprio jogo político controlado pelas forças dominantes dessa era. Se a terceirização é mais uma "fatalidade" dos tempos modernos, contra a qual não se pode lutar, então a única alternativa é

${ }^{16}$ A primeirização dos postos de trabalho, defendida pela CNQ, é desfazer as contratações através da terceirização e contratar diretamente os trabalhadores pelas empresas. 
colocar alguns limites a essa prática, a fim de minorar os seus efeitos sobre os trabalhadores. Tratase de uma atuação que contribui fortemente para legitimar e legalizar a terceirização, com o aval propositivo dos representantes dos trabalhadores, a exemplo do referido Projeto de Lei da Central Única dos Trabalhadores.

Mas, ao lado dessa postura, chama a atenção uma tendência relativa ao número de greves de trabalhadores terceirizados que ocorre no país. Embora não se disponha de estatísticas oficiais e sistematizadas por outras instituições acerca desse processo, em consultas a alguns jornais da grande imprensa e a sites de busca, é possível perceber que diariamente há notícias sobre movimentos grevistas de terceirizados que, na sua maior parte, reivindicam pagamento de salários atrasados, de décimo terceiro, de férias e depósitos do FGTS, ou seja, os direitos básicos garantidos aos trabalhadores com carteira assinada que não estão sendo cumpridos por essas empresas.

Além disso, há também um esforço de sindicatos na luta contra a terceirização, a exemplo da criação de departamentos ou secretarias de terceirizados nos grandes sindicatos, incorporação da representação sindical dos terceirizados junto aos trabalhadores contratados diretamente, grupos de discussão sobre os projetos de lei e ações contra a terceirização, organização e criação de sindicatos de trabalhadores terceirizados e, mais recentemente, a inclusão, nas pautas de reivindicações das campanhas salariais e dissídios dos grandes sindicatos, das pautas específicas dos terceirizados (em relação a salários, jornadas de trabalho, participação nos lucros, horas extras, prevenção de acidentes, cobertura de planos de saúde, transportes, alimentação, dentre outras). Dentre os exemplos mais fortes dessas iniciativas, estão o da Confederação Nacional dos Bancários, que passou a lutar para representar os trabalhadores terceirizados dos bancos e instituições financeiras, o caso mais ilustrativo dos trabalhadores em telemarketing, e o da Federação Única dos Petroleiros, que na última greve geral realizada em 2009, incorporou em sua pauta as reivindicações dos terceirizados da
Petrobras e contou com a adesão desses trabalhadores na maioria dos estados (Druck, 2011b).

\section{- Um sexto tipo de precarização social do trabalho: a condenação e o descarte do Direito do Traba- $1 h o^{17}$}

Por fim, e não menos importante, a fetichização do mercado ${ }^{18}$ tem orquestrado e decretado uma "crise do Direito do Trabalho", questionando a sua tradição e existência, o que se expressa no ataque às formas de regulamentação do Estado, cujas leis trabalhistas e sociais têm sido violentamente condenadas pelos "princípios" liberais de defesa da flexibilização, como processo inexorável trazido pela modernidade dos tempos de globalização.

O debate entre os profissionais e especialistas do setor reflete opiniões que se dividem: há os que sustentam a defesa do Direito do Trabalho e seu princípio protetor, reconhecendo a desigualdade e a inferioridade econômica dos trabalhadores na sociedade capitalista, mais forte na era atual, o que exige, portanto, mais direitos e proteção social; e há aqueles que, em nome dos princípios liberais, afirmam o respeito à individualidade do trabalhador, que, ao "depender" do Estado (pela estrutura dos direitos sociais), estaria supostamente impedido de desenvolver as suas qualidades e atributos livremente no trabalho, dificultando, dessa forma, o próprio desenvolvimento do mercado capitalista na atual conjuntura de desregulamentação mundial.

No Brasil, as alterações já realizadas na Consolidação das Leis do Trabalho (CLT), nos anos 1990, e a defesa atual de uma reforma trabalhista "moderna", que corresponda "às mudanças no mundo do trabalho", enquadram-se nessa segunda defesa, isto é, que, para o livre funcionamento

${ }^{17}$ Esse último tipo de precarização está sendo acrescentado aos demais cinco tipos que foram formulados por Franco e Druck (2009), conforme foi referido no texto.

${ }^{18}$ Aqui, a fetichização é usada no sentido marxista, quando o mercado e as mercadorias"assumem vida própria”, autonomizando-se em relação aos sujeitos sociais, e dessa forma, querem prescindir de qualquer limite à sua autonomia e liberdade, especialmente a liberdade de exploração do trabalho que, em tempos neoliberais, impõe a desregulamentação do estado e a retirada dos direitos. 
do mercado, seria preciso retirar os limites, ou seja, retirar os encargos sociais elevados (direitos sociais e trabalhistas), considerados como entulhos da velha e ultrapassada CLT, que já teria cumprido a sua função num momento histórico já superado.

Num outro campo - o da ação do poder público-, a disputa em torno do fim do Direito do Trabalho ou da sua manutenção se intensifica através do papel que jogam ou podem jogar alguns órgãos ou instituições públicas, que têm como função primordial assegurar a aplicação e o respeito à legislação em vigor. No caso do Ministério do Trabalho e Emprego (MTe), a ação dos auditores fiscais - com a liberdade e independência hierárquica que lhes é de direito, ao fiscalizar, autuar e multar as empresas e instituições, respaldados na lei tem sido motivo de questionamento e já foi objeto de projeto de lei voltado para lhes retirar esse poder, ${ }^{19} \mathrm{o}$ que gerou ampla mobilização dos agentes de fiscalização e dos sindicatos, que fizeram retroceder tal proposta.

O Ministério Público do Trabalho (MPT), por sua vez, tem sido objeto de fortes críticas veiculadas pela grande imprensa, na voz de empresários e até mesmo de sindicalistas, que acusam os promotores de atuarem como empecilhos para a abertura de novos empregos, ao exigirem respeito à legislação, já que estariam dificultando a ação empresarial.

Na realidade, são instituições que têm um papel fundamental como agentes dotados de poderes para colocar limites à ação do capital - através da regulamentação - na relação de mercantilização do trabalho, a qual, nos últimos tempos, tem ido mais além da compra e venda da força de trabalho através do assalariamento, pois vem se utilizando

\footnotetext{
${ }^{19}$ Foi o caso da Emenda 3 ao Projeto de Lei que criou a Super Receita, em 2007, que proibia os auditores fiscais de autuarem ou fecharem as empresas prestadoras de serviço constituídas por uma única pessoa, se verificassem que a relação de prestação de serviços com uma outra empresa, na verdade, configura uma relação trabalhista. E transferia para o Poder Judiciário a definição de vínculo empregatício, beneficiando profissionais liberais que atuam como pessoas jurídicas e as empresas que utilizam seus serviços, em substituição ao contrato de trabalho pela CLT. Aprovada no Congresso, a Emenda foi vetada pelo presidente Lula, após ampla mobilização dos sindicatos, inclusive do Sindicato Nacional dos Auditores Fiscais do Trabalho (SINAIT).
}

de outras formas que pareciam estar superadas, a exemplo do trabalho infantil e do trabalho análogo ao escravo.

Nesse sentido, a atuação conjunta do Ministério do Trabalho e Emprego e do Ministério Público do Trabalho, com o apoio da Polícia Federal, no combate ao trabalho análogo ao escravo, ${ }^{20}$ tem sido efetiva, com resultados muito expressivos, seja em número de trabalhadores resgatados, como na repercussão política dessa atuação, que tem revelado o grau de exploração de modernas empresas nacionais e multinacionais no Brasil, e que deu origem ao "Cadastro de Empregadores flagrados explorando mão de obra escrava”, conhecido como "Lista Suja" e disponível no site do MTe. No período de 2000 a 2010, foram realizadas 959 operações nas diversas regiões do país, onde foram resgatados 37.092 trabalhadores e um total de 35.790 trabalhadores tiveram seus contratos formalizados a partir da ação dos fiscais. O valor do pagamento de indenizações relativas a dívidas salariais (saldo de salários, férias, décimo terceiro, gratificação natalina etc) atingiu a cifra de $\mathrm{R} \$ 61,2$ milhões, nesses dez anos, sem incluir as multas e indenizações por danos morais.

Essas ações mostram, de um lado, um alto crescimento do recurso ao trabalho escravo no contexto dos tempos modernos do trabalho, que se torna visível, a partir de denúncias e da realização dessas operações coordenadas pelo MTE; de outro, indicam a capacidade que o Estado tem, quando assim o quer e decide, de pôr limites à voracidade do capital.

Esse exemplo, dentre outros, é representativo, por si só, da ausência de limites morais do capital e explicita por que o Direito do Trabalho é colocado em questão, ao tempo que indica a importância da ação regulatória do poder público, como agente do Direito do Trabalho brasileiro, que tanto incomoda os radicais defensores da ordem neoliberal.

${ }^{20}$ Trabalhadores resgatados por trabalho análogo ao escravo, conforme art.149 do Código Penal, são aqueles que atuam nas seguintes condições: trabalho forçado, servidão por dívida, jornada exaustiva e (ou) trabalho degradante (Mte, www.mte.gov.br) Para uma análise sobre essa condição, ver Filgueiras (2010). 
Vale ainda destacar a experiência singular no estado da Bahia, com a formação do FORUMAT - Fórum de Proteção ao Meio Ambiente do Trabalho no Estado da Bahia, que reúne um conjunto de instituições, como: Ministério Público do Trabalho, Delegacias Regionais do Trabalho, Fundacentro, Centro de Estudos de Saúde do Trabalhador CESAT/SESAB e sindicatos de trabalhadores. Com destaque para a atuação do Ministério Público do Trabalho, proponente e coordenador do Fórum, cuja independência e autonomia têm garantido uma prática que vem impondo o cumprimento da legislação, fazendo recuar a terceirização e a precarização do trabalho em várias empresas públicas e privadas. A existência desse Fórum representa a defesa do papel do Direito do Trabalho, cuja origem se justifica pelo grau de desigualdade e assimetria das relações entre empregados e empregadores que, em tempos neoliberais, se agrava ainda mais, resultando numa relação de forças extremamente desproporcional e desfavorável aos trabalhadores (Druck; Franco, 2007).

\section{COMENTÁRIOS FINAIS: novos ou velhos desafios?}

A conjuntura atual do trabalho no Brasil, embora venha motivando declarações ufanistas em torno do crescimento do emprego com carteira assinada, não pode ser analisada a partir do "fetiche dos números". É o que se procurou indicar neste artigo, ao se analisar o momento histórico caraterizado pelo capitalismo flexível, cuja configuração contemporânea -e estrutural -, definida pela mundialização do capital hegemonizada pela esfera financeira, tem, na precarização social do trabalho, o centro da sua dinâmica.

Nessa medida, considera-se que o aspecto central que explica a estrutura capitalista hoje é o grau ilimitado da mercantilização do trabalho e da vida, conforme explicitam as dimensões do processo de precarização como indicadores qualitativos aqui apresentados. Se, na conjuntura mais recente, os números indicam a queda do desemprego e a recuperação do emprego, cabe refletir, como afirmou Juan Somavia, diretor geral do OIT, que:

... além da taxa de desemprego, temos o desafio de melhorar a produtividade e os salários, reduzir a informalidade, melhorar a cobertura da proteção social e enfrentar as desigualdades [...]. Não é só importante gerar mais empregos, mas que estes empregos sejam de qualidade”. ${ }^{21}$

É preciso ainda ir mais além, para definir o que são empregos de qualidade, num momento em que essa mercantilização atingiu níveis extremos, encoberta pelo fetichismo do mercado, banalizando os riscos, os acidentes e a saúde dos trabalhadores, conforme indica o crescimento do número de acidentes de trabalho, e desrespeitando normas elementares de segurança do trabalho, conforme é revelado pelas fiscalizações do MTE. Tal quadro é agravado por uma política de monetarização da saúde e dos riscos, que passa a pautar as negociações e julgamentos da Justiça do Trabalho, em contraposição às determinações de políticas de prevenção e proteção, principalmente, o controle do seu exercício.

Na perspectiva do capital, a monetarização e a mercantilização das relações de trabalho transformam os direitos dos trabalhadores em "custos" (o "custo Brasil”, o "custo China”) e invadem também o ideário dos trabalhadores e de suas lideranças sindicais, que passam a interiorizar a lógica do mercado, tomando-a como sua. Isso é estimulado ainda pela concorrência entre os próprios trabalhadores, expressa em disputas regionais, a exemplo da guerra fiscal no país, que faz competir não somente os estados, através da ação de seus governos, mas também os trabalhadores de uma região com os de outra região.

Tais transformações, ao tempo que reafirmam a essência do capitalismo, que transformou o trabalho em mercadoria, dão outra amplitude a essa relação social, ao enfraquecerem a capacidade de resistir e de questionar as novas condições impostas pelo capital, numa clara demonstração de

${ }^{21}$ Discurso de abertura da $17^{\mathrm{a}}$ Reunião Regional da OIT realizada no Chile em 14 de dezembro de 2009, conforme www.oit.org.pe/americas2010/ESP/. 
uma atitude de resignação que, aos poucos, contamina até mesmo a capacidade de indignação diante das injustiças sociais, da negação dos direitos e da proteção social, encaradas como uma "fatalidade econômica”.

Talvez a maior dificuldade, tanto no âmbito da ação política como no campo dos estudos acadêmicos, seja a pressa em identificar, nomear e classificar o que há de novo no mundo do trabalho, a fim de caracterizar as rupturas que anunciam um novo tipo de sociedade - pós-capitalista, pós-moderna, pós-emprego, pós-fordista ou pósneoliberal -, como se esse processo de mudanças tivesse uma evolução linear.

Por isso, as análises apoiadas numa perspectiva histórico-dialética podem ajudar em muito a desvendar as contradições contemporâneas do capitalismo. Assim, o esforço analítico aqui adotado foi o de buscar demonstrar as principais metamorfoses do trabalho, explicitadas nas diversas dimensões do processo de precarização social do trabalho (e tipos), as quais, mesmo no Brasil - país tradicionalmente marcado pelo trabalho precário em todas as suas dimensões, cuja origem maior está no trabalho escravo e nas formas assumidas pela sua transição ao trabalho assalariado -, se reconfiguraram ou se redefiniram, apresentando, hoje, uma precarização antiga e moderna, metamorfoseada.

Considera-se, portanto, que, ao lado do "novo espírito do capitalismo", caracterizado por Boltanski e Chiapello (2009) como um fatalismo dominante, e da impotência da crítica social, há um "velho espírito do capitalismo" que ressalta suas contradições, suas incoerências e seus limites. Mesmo assim, ainda se encontra a defesa da utopia da sua superação através de uma crítica radical, mesmo que de forma pontual e minoritária.

Por fim, compreende-se que há velhos e novos desafios. Saber combiná-los e tirar as conclusões e consequências exige muita sabedoria e reflexão. Talvez um começo para essas reflexões se encontre na convenção definida na Conferência de Filadélfia, em 1944, que consolida a construção da Organização Internacional do Trabalho: "o tra- balho não é uma mercadoria!” O que leva a questionar o centro da dinâmica capitalista ontem e hoje. Que consequências - teóricas e práticas - se podem inferir dessa afirmação? São possíveis reformas que implementem o "trabalho decente" sem rupturas com o atual padrão de capitalismo, construído na era da globalização financeira? Esse é o grande desafio. Nem "novo", nem "velho": o de sempre.

(Recebido para publicação em 30 de outubro de 2010) (Aceito em 03 de fevereiro de 2011)

\section{REFERÊNCIAS}

ANDERSON, P. Balanço do neoliberalismo, In: SADER, E; GENTILI, P. (Org.) Pós-neoliberalismo - as políticas sociais e o estado democrático. Rio de Janeiro: Paz e Terra, 1995. 205p.

APPAY, B. La dictadure du succès: le paradoxe de l'autonomie contrôlée et de la précarisation. Paris: L'Hartattan, 2005. 262 p.

BESSON, J. (Org.) A ilusão das estatísticas. São Paulo: Editorial UNESP, 1995. 289p.

As estatísticas: verdadeiras ou falsas? In: $\overline{\text { (Org.) A }}$ ilusão das estatísticas. São Paulo: Ed. UNESP, 1995. 289p.

BOLTANSKI, L.; CHIAPELLO, E. O novo espírito do capitalismo. São Paulo: Ed.WMF Martins Fontes, 2009. 701p. BORGES, A.; DRUCK, G. Crise global, terceirização e a exclusão no mundo do trabalho. Caderno CRH: Centro de Recursos Humanos da UFBA, Salvador, n.19, 1993

BOURDIEU, P. A precariedade está hoje por toda parte. In: . Contrafogos, Rio de Janeiro: Ed. Jorge Zahar, 1998, p.119-127.

CASTEL, R. As metamorfoses da questão social: uma crônica do salário. Rio de Janeiro: Ed. Vozes, 1998. 611p.

DIEESE. Departamento Intersindical de Estudos Econômicos. O processo de terceirizacão e seus efeitos sobre os trabaIhadores. Convênio SE/MTE Nº. 04/2003-DIEESE, 2007.

DRUCK, G. A precarização social do trabalho no Brasil: uma proposta de construção de indicadores. Salvador: CRH/ UFBA/CNPq. Projeto de Pesquisa Bolsa Produtividade do CNPq, 2007/2010 (mimeo).

O avanco da terceirização do trabalho: principais tendências nos últimos 20 anos no Brasil e na Bahia. Revista Bahia Análise e Dados, Salvador, n.especial, 2011b. (no prelo)

Precarização e informalidade: algumas especificidades do caso brasileiro, In: VERAS, Roberto (Org.) sem título., 2011a. (No prelo)

OLIVEIRA, L.P.; SILVA. S. A precarização social do trabalho no Brasil: o caso da vulnerabilidade dos jovens e dos sindicatos. In: BRAGA, T.; VIDAL, F. NEVES, L. (Org.) Trabalho em questão. Salvador: SEI, 2010. p.103129. (Série estudos e pesquisas, 86) 
FILGUEIRAS, V. Trabalho análogo ao escravo e o limite da relação de emprego no Brasil. In: REUNIÃO INTERMEDIARIA TRABALHO E SINDICALISMO - O TRABALHO E NOVAS DINÂMICAS LOCAL-GLOBAL, 4, 2010, Campina Grande, Anais.... Campina Grande, 2010, p.172191.

FRANCO, T; DRUCK, G. O trabalho contemporâneo no Brasil: terceirização e precarização. In: SEMINÁRIO FUNDACENTRO. Salvador, 2009. (mimeo).

- SELIGMANN-SILVA, E As novas relações de trabalho, o desgaste mental do trabalhador e os transtornos mentais no trabalho precarizado. Revista Brasileira de Saúde Ocupacional, São Paulo, Fundacentro, v.35, n.122, p.229-248, 2010.

HARVEY. D. A condição pós-moderna. São Paulo: Loyola, 1992. $349 \mathrm{p}$.

IBGE/PNAD. Instituto Brasileiro de Geografia E Estatística. Pesquisa Nacional por Amostra de Domicílio: período de 2001-2009. Rio de Janeiro, 2009.

JANUZZI, P. de M. Indicadores sociais no Brasil: conceitos, fontes de dados e aplicações, Campinas. 2.ed. São Paulo: Ed. Alínea, 2003

MTe. Ministério do Trabalho em Emprego. Agenda Nacional do Trabalho Decente. Brasília, 2006.

Divisão de Fiscalização para Erradicação do Trabalho Escravo (DETRAE), Quadro Geral das Operacões de Fiscalização para Erracadicação do Trabalho Escravo (SITSRTE) 1995-2010. Disponível em: www.mte.gov.br. Acesso em: 27 dez 2010.

OIT/CEPAL/PNUD. Emprego, desenvolvimento humano e trabalho decente: a experiência brasileira recente. Brasília, OIT, CEPAL, PNUD, 2008.
Trabalho decente nas Américas: uma agenda hemisférica 2006-2015. In: REUNIÃO REGIONAL AMERICANA, 16, 2006, Brasília.

World of Work Report 2009. The global jobs crisis and Beyond. Beyond: 2009a.

Para superar a crise: um pacto mundial para o emprego da OIT. Edição 10/11/2009. Lima: Escritório Regional da OIT para a América Latina e o Caribe, 2009b.

. Sumário Executivo - World of Work Report 2008: ncome inequalities in the age of financial globalization. Genebra: Instituto Internacional de Estudios Laborales, 2008 . Juventud e trabajo decente. Lima: OIT /Oficina Regional para América Latina y el Caribe, 2007.

Perfil do trabalho decente no Brasil. Brasília. Escritório da OIT Brasil, 2006.

SANTANA, R. Práticas de Terceirização nas empresas industriais. In: DRUCK, G.; FRANCO, T. (Org.) A perda da razão social do trabalho: terceirização e precarização. São Paulo: Ed Boitempo, 2007. p.169-187.

SELIGMANN-SILVA, E. Desemprego e psicopatologia da recessão. In: BORGES, L. H.; MOULIN, M. G. B.; ARAUJO, M. D. (Org.) Organização do trabalho e saúde: múltiplas relações. Vitória: UFES, 2001. p.219-254

SENNETT, R. A corrosão do caráter: impactos pessoais no capitalismo contemporâneo. São Paulo: Ed Record, 1999.

THEBAUD-MONY, A.; DRUCK, G. Terceirização: a erosão dos direitos dos trabalhadores na França e no Brasil. In DRUCK, G.; FRANCO, T. (Org.) A perda da razão social do trabalho: terceirização e precarização. São Paulo: Ed Boitempo, 2007. p.23-58. 


\section{LABOR, PRECARIZATION AND RESISTANCES: old and new challenges}

\section{Graça Druck}

This paper discusses why the precarization of labor is an old and young phenomenon, different and equal, past and present, a phenomenon of a macro- and microssocial character. It presents some fetishes present in the analysis of labor in the context of globalization of capital, marked by the hegemony of finance capital, the restructuring of production and labor and a "new spirit of capitalism." There are five sections: introduction, discussion of methodological issues based on reflections of research projects in progress, theoretical considerations on the characterization of flexible capitalism and the centrality of social precarization of labor, a contextualization of labor in Latin America and Brazil in the light of ILO studies, indicators of precarization and resistances, and a debate on the new and old challenges brought about by the changes under the aegis of the social precarization of labor and a "spirit of capitalism" reformulated, which, while reaffirming the old spirit, constitutes a new spirit.

KEYwORDS: labor, precarization, resistances, social indicators.

\section{TRAVAIL, PRÉCARISATION ET RÉSISTANCES: anciens et nouveaux défis}

\section{Graça Druck}

L’article explique en quoi la précarité du travail est à la fois ancienne et nouvelle, semblable et différente, passée et présente, en quoi elle est un phénomène de nature macro et micro sociale. On y présente quelques fétiches qui se trouvent dans les analyses sur le travail pris dans le contexte de la mondialisation du capital, marqué par l'hégémonie du capital financier, la restructuration de la production et du travail et un "nouvel esprit du capitalisme". Il se divise en cinq parties: l'introduction; l'analyse des questions méthodologiques fondées sur les réflexions des projets de recherche en cours ; les considérations théoriques concernant la caractérisation du capitalisme flexible et la centralité de la fragilisation sociale du travail ; la contextualité du travail en Amérique Latine et au Brésil, à la lumière des études de l’OIT, des indicateurs de précarité et de résistances ; et un débat concernant les anciens et les nouveaux défis issus des transformations sous l'égide de la fragilisation sociale du travail et d'un "esprit du capitalisme" reformulé qui, tout en réaffirmant l'ancien esprit, en constitue un nouveau.

Mots-Clés: Le travail, la précarisation, les résistances, les indicateurs sociaux.

Graça Druck - Doutora em Ciências Sociais, com pós-doutorado na Universidade de Paris XIII. Professora associada I do Departamento de Sociologia e da Pós-Graduação em Ciências Sociais da Universidade Federal da Bahia - PPGCS/FFCH/UFBA. Pesquisadora do Centro de Recursos Humanos/FFCH/UFBA e do CNPq. Realiza pesquisas na área de Sociologia do Trabalho. Autora do livro Terceirização: (Des)Fordizando a Fábrica - um estudo do complexo petroquímico da Bahia (Ed. Boitempo/Edufba, 1999 e 2001) e coorganizadora do livro A perda da razão social do trabalho: precarização e terceirização. (Ed. Boitempo, 2007). Tem artigos publicados em diversos periódicos, Revista Latinoamericana de Estudios del Trabajo -; Pistes; Laboreal; Revista Brasileira de Saúde Ocupacional; Caderno CRH). 